\title{
Evaluation of genetic diversity for yield and quality parameters of different potato (Solanum tuberosum L.) germplasm
}

\author{
Sanjay Datta ${ }^{1}$, Rajib Das ${ }^{2 *}$ and Dhirendra Singh ${ }^{1}$ \\ ${ }^{1}$ Department of Vegetable Science, College of Agriculture, G.B. Pant University of Agriculture and Technology, \\ Pantnagar- 263145, (Uttarakhand), INDIA \\ *2Department of Vegetable Crops, Faculty of Horticulture, Bidhan Chandra Krishi Vishwavidyalaya, Mohanpur, \\ Nadia - 741252 (W.B.), INDIA \\ *Corresponding author. E-mail: rajib_bckv@yahoo.co.in
}

Received: August 25, 2014; Revised received: February 20, 2015; Accepted: April 10, 2015

\begin{abstract}
An investigation was carried out at Vegetable Research Centre, G.B. Pant University of Agriculture and Technology, Pantnagar during spring-summer season 2011 and 2012 to study the genetic diversity using Mahalanobis's $D^{2}$ - technique among thirty five potato (Solanum tuberosum L.) germplasm for important yield attributing and quality traits. The $D^{2}$ values were calculated and thirty five potato genotypes were grouped into nine clusters for growth characters and ten clusters for quality traits respectively. All the genotypes included in the present investigation, were indigenous, but their grouping in different clusters, suggested that genotypes did not follow the geographic distribution. The cluster I contained the maximum number of genotypes with respect to both yield attributing and quality traits. The inter cluster distance in most of the cases were higher than the intra-cluster distance indicating wider genetic diversity among the genotypes of different groups. Average tuber weight of potato plant contributed maximum $(31.76 \%)$, followed by number of tuber per plant $(27.56 \%)$, internodal length $(14.45 \%)$ and plant dry matter content $(13.61 \%)$ for growth characters. For quality characters, ascorbic acid content $(24.70 \%)$, protein content of tuber $(20.84 \%)$ and TSS of tuber $(20.00 \%)$ contributed effectively towards genetic divergence. So, these traits will offer a good scope for improvement of yield and quality through rational selection of parental genotypes for future potato breeding. The findings indicated that use of parents selected from the same cross or from a cross involving a common parent should be avoided in hybridization. The results broadly showed there was no parallelism between geographical and genetic divergence.
\end{abstract}

Keywords: Genetic diversity, Germplasm, Mahalanobis's $D^{2}$ technique, Solanum tuberosum, Yield traits

\section{INTRODUCTION}

Besides its significance to human food security, potato (Solanum tuberosum) is also a crop with fascinating genetic traits and cultural history (Swaminathan, 1999). Exploitation of variability displayed by different Solanum germplasm for breeding the cultivated potato (S. tuberosum) requires phenotypic and genotypic characterization of germplasm resources (Barone et al., 2010). Selection and hybridization are the two basic methods for improving crop plants. Selections concentrate favorable genes in cultivars for better performance. The success of selection and hybridization programme depends upon the extent of variability, heritability and association among yield contributing characters and quality traits and their effects upon yield and quality (Rizvy et al., 2007).

Identification of diverse but desirable parents remained a difficult task for plant breeders. In the past, generally, ecological or geographic diversity has been considered as an index of genetic diversity. However, this is an inferential criterion, and may not be so effective in quantification and differentiation between populations. Therefore, genetic divergence analysis is highly essential to estimate the extent of diversity existed among selected genotypes (Mandal, 2003).

Genetic diversity is used for discriminating divergent populations, which are reinstated by more scientific and advanced biometrical techniques viz., multivariate analysis based on Mahalanobis $\mathrm{D}^{2}$-statistic (Mahalanobis, 1936). The success of potato breeding programs depends on identification of the amount and distribution of genetic diversity in the gene pool, to identify the gaps in germplasm collections and to develop effective conservation and management strategies (Esfahani et al., 2009). Selection as well as hybridization programme from locally available germplasm result in minor progress in development of varieties because of low variability in the germplasm available. Diverse genetic materials are, therefore required to meeting the ever-increasing demands of plant improvement. Information on genetic diversity in available germplasm collection is therefore, of paramount importance. Therefore, success in development programme of potato 
can be achieved through utilization of the broad genetic base of cultivated, as well as wild relatives of crop plants available in different parts of the world in this crop species (Ragassa et al., 2007). Keeping view towards the above facts and to characterize potato germplasm, the present study was under taken with the objective to study genetic diversity among potato genotypes for important yield attributing and quality traits of S. tuberosum.

\section{MATERIALS AND METHODS}

The present investigation was carried out at Vegetable Research Centre, G.B. Pant University of Agriculture and Technology, Pantnagar during spring-summer season 2011 and 2012. Pantnagar is situated at $29.5^{\circ}$ latitude and $79.3^{\circ} \mathrm{E}$ longitude and at an altitude of 243.84 meters above the mean sea level in sub-mountainous region of Shivalik hills, known as Tarai. The climate of this place is humid and sub-tropical and frost can be expected from last week of December to end of the January. The experimental materials comprised of thirty five genotypes of potato including twelve commercially released varieties from Central Potato Research Institute (CPRI), Shimla, Himachal Pradesh and one commercially released variety from G. B. Pant University of Agriculture and Technology, Pantnagar and twenty two breeding lines under trial at Central Potato Research Institution, Shimla, Himachal Pradesh (Table 1). The tubers were planted $(60 \mathrm{~cm} \times 20 \mathrm{~cm})$ in a $5.4 \mathrm{~m}^{2}$ plots in the month of October. The fertilizers were applied@160: 100: 120 (NPK kg/ha) in the form of Urea, single super phosphate and muriate of potash, respectively. All other cultivation practices were carried out following the standard cultivation procedure applicable for potato cultivation in this region.

The experiment was conducted in randomized block design with each treatment replicated three times and the pooled mean values were used for statistical analysis as per methods suggested by Panse and Sukhatme (1989). The observations were recorded manually on whole population basis for various yield attributing and quality traits (as presented in tables 2 to 7). Five plants per plot were selected randomly for each genotype. The genetic divergences in thirty five genotypes were estimated by Mahalonobis " $D$ "" statistics (generalized distance). Treating $\mathrm{D}^{2}$ as the square of generalized distance, all genotypes were grouped into a number of clusters, according to the methods described by Tocher (Rao, 1952). The relative contribution of different characters to the total $\mathrm{D}^{2}$ between each pair of genotypes was given a score of 1 to 20 (total number of characters) based on the magnitude of the $\mathrm{D}^{2}$ value due to each character.

\section{RESULTS AND DISCUSSION}

Analysis of genetic diversity and clustering pattern of potato genotypes: Using statistic proposed by Mahalonobis, $\mathrm{D}^{2}$ values were calculated and thirty five potato genotypes were grouped into nine clusters for growth character (Table 2) and ten clusters for quality characters (Table 3 ), respectively, indicating genetic diversity among them. Maximum number of genotypes fell in the cluster-I for growth characters and the number of genotypes was 14 [viz. Kufri Puskar, Kufri Bahar, Kufri Pukhraj, Kufri Badshah, Kufri Sutlej, Kufri Lalima, B-420(2)/Red, J/93-81，JX/576，J/93-139，J/92-167, $\mathrm{MS} / 92-3146, \mathrm{MS} / 92-3128$ and MS/92-209]. For quality character, the maximum ten numbers of genotypes [viz. J/93-81, MS/92-542, MS/92-209, J/94-90, J/93-4, $\mathrm{J} / 92-167, \mathrm{~J} / 92-159, \mathrm{~J} / 95-242, \mathrm{MS} / 95-117$ and Kufri Ashoka] fell in the cluster-I showing genetic similarities among themselves. Different growth characters like plant height, average tuber weight, number of tubers per plant, plant dry matter content which had higher contribution to total divergence. Whereas, for quality, minor difference were observed among different characters like ascorbic acid, protein content and total soluble solid (TSS) of tuber for individual contribution towards total divergence. Among the nine clusters for growth characters, cluster-II, IV, VI, VIII and XI consisted of single genotypes, namely Kufri Anand, MP/91-132, MS/92 -542, Pant Selection-1 and Kufri Chipsona-2 respectively, which indicate high genotypic differences among themselves. Similarly, for quality attributes, cluster-IX (J/93-3128) and cluster-X (JX/576) having one genotype each, showing high genetic divergence among these genotypes from the others. Razvy et al. (2007) studied the genetic diversity using Mahalanobis's D - technique for tuber yield and its components viz., Plant Height, Number of Leaves/plant, Fresh Weight/plant, Number of Tubers/plant, Number of Eyes/tuber, Average Tuber Weight of Plant and Tuber weight/plant. The 30 potato genotypes were grouped into six clusters. The maximum diversity was contributed by tuber weight/plant $(0.1341)$ followed by average tuber weight/plant (0.0462), plant height $(0.0365)$, fresh weight/ plant (0.0156) and number of leaves/plant $(0.0085)$. The outcomes of the research work conducted by Razvy et al. (2007) are in good agreement with the results of the present experiment. From the results obtained in this investigation, genotypes in highly divergent clusters having many desirable characters could be taken into account for further use.

Intra and inter cluster divergence: The intra and inter cluster divergence (average $\mathrm{D}^{2}$ values) of all clusters has been presented in the Tables 4 and 5. Intra-cluster average $\mathrm{D}^{2}$ values ranged from 0.00 to 131.72 for growth characters and for quality characters, it ranged from 0.00 to 9.84 . In quality characters, cluster-VIII showed maximum intra $\mathrm{D}^{2}$ values with two genotypes and clusters-IX, X showed minimum intra $\mathrm{D}^{2}$ value each with one genotype. The inter-cluster average $\mathrm{D}^{2}$ values for growth characters was maximum (478.65) between cluster- V and VII and 29.97 between clusters IX and $\mathrm{X}$, respectively. The minimum inter- cluster values for quality characters was 5.05 between cluster 
Table 1. List of potato (S. tuberosum) genotypes, source and parentage.

\begin{tabular}{|c|c|c|c|}
\hline S.N. & Genotype & Source & Parentage \\
\hline 1 & Kufri Badshah & CPRI,Shimla & Kufri Jyoti X Kufri Alankar \\
\hline 2 & Kufri Ashoka & -do- & EM/C-1020 X Allerfriiheste Gelbe \\
\hline 3 & Kufri Jyoti & -do- & 3069 d (4) X 2814 a (1) \\
\hline 4 & Kufri Puskar & -do- & - \\
\hline 5 & Kufri Anand & -do- & PJ-376 X PH/F -1430 \\
\hline 6 & Kufri Sutlej & -do- & Kufri Bahar X Kufri Alankar \\
\hline 7 & Kufri Pukhraj & -do- & Craig's Defiance X JEX/B-687 \\
\hline 8 & Kufri Jawahar & -do- & Kufri Neelamani X Kufri Jyoti \\
\hline 9 & Kufri Lalima & - do- & Kufri Red X AG-14(Wis X 37) \\
\hline 10 & Kufri Bahar & -do- & Kufri Red X Gineke \\
\hline 11 & Kufri Chipsona-2 & - do- & F-6 X QB/B 92-4 \\
\hline 12 & Pant Selection-1 & -do- & - \\
\hline 13 & Kufri Arun & - do- & - \\
\hline 14 & $\mathrm{~J} / 95-227$ & -do- & - \\
\hline 15 & $\mathrm{~J} / 92-159$ & - do- & - \\
\hline 16 & MS/92-1090 & -do- & - \\
\hline 17 & MP/91-132 & -do- & - \\
\hline 18 & $\mathrm{~J} / 93-86$ & -do- & - \\
\hline 19 & MS/92-209 & -do- & - \\
\hline 20 & $\mathrm{MS} / 92-3128$ & -do- & $\mathrm{MS} / 82-27 \mathrm{X} \mathrm{MS} / 82-758$ \\
\hline 21 & MS/95-1309 & -do- & - \\
\hline 22 & $\mathrm{~J} / 93-139$ & -do- & - \\
\hline 23 & $\mathrm{MS} / 92-3146$ & - do- & - \\
\hline 24 & B-420(2) & - do- & - \\
\hline 25 & $\mathrm{~J} / 93-81$ & - do- & - \\
\hline 26 & MS/92-542 & - do- & - \\
\hline 27 & $\mathrm{~J} / 93-87$ & -do- & - \\
\hline 28 & $\mathrm{~J} / 95-242$ & - do- & - \\
\hline 29 & $\mathrm{~J} / 93-4$ & -do- & - \\
\hline 30 & $\mathrm{~J} / 92-167$ & - do- & - \\
\hline 31 & $\mathrm{~J} / 94-90$ & -do- & - \\
\hline 32 & JX/576 & -do- & - \\
\hline 33 & 91-P-27 & -do- & - \\
\hline 34 & MS/92-13 & -do- & - \\
\hline 35 & MS/95-117 & -do- & - \\
\hline
\end{tabular}

Table 2. Clustering pattern of thirty five genotypes of potato on the basis of genetic divergence among growth parameters.

\begin{tabular}{|c|c|c|c|}
\hline S. $\mathbf{N}$. & Cluster & No. of genotype & Genotypes \\
\hline 1 & I & 14 & $\begin{array}{l}\text { Kufri Puskar, Kufri Bahar, Kufri Pukhraj, Kufri Badshah, Kufri } \\
\text { Sutlej, Kufri Lalima, B-420(2)/Red, J/93-81, JX/576, J/93-139, J/92 } \\
-167, \text { MS/92-3146, MS/92-3128 and MS/92-209 }\end{array}$ \\
\hline 2 & II & 1 & Kufri Anand \\
\hline 3 & III & 8 & $\begin{array}{l}\text { J/95-242, J/95-227, J/93-87, J/94-90, J/93-86, MS/92-13, MS/95- } \\
117, \text { MS/92-1090 }\end{array}$ \\
\hline 4 & IV & 1 & $\mathrm{MP} / 91-132$ \\
\hline 5 & $\mathrm{~V}$ & 6 & $\begin{array}{l}\text { J/92-159, J/93-4, MS/95-1309, Kufri Ashoka, Kufri Jawahar and } \\
\text { Kufri Jyoti }\end{array}$ \\
\hline 6 & VI & 1 & MS/92-542 \\
\hline 7 & VII & 2 & 91-P-27, Kufri Arun \\
\hline 8 & VIII & 1 & Pant Selection-1 \\
\hline 9 & IX & 1 & Kufri Chipsona-2 \\
\hline
\end{tabular}


Table 3. Clustering pattern of thirty five genotypes of potato on the basis of genetic divergence among quality parameters.

\begin{tabular}{cccl}
\hline S. N. & Cluster & $\begin{array}{c}\text { No. of geno- } \\
\text { type }\end{array}$ & \multicolumn{1}{c}{ Genotypes } \\
\hline 1 & I & 10 & J/93-81, MS/92-542, MS/92-209, J/94-90, J/93-4, J/92-167, J/92-159, \\
& II & 6 & MS-242, MS/95-117, Kufri Ashoka \\
2 & III & 5 & Kufri Jyoti, Kufri Lalima, Kufri Sutlej, Kufri Jawahar, Kufri Pukhraj \\
3 & IV & 4 & MS/95-1309, MS/92-3146,J/95-227, Ms/92-13 \\
4 & V & 2 & Kufri Anand, Kufri Bahar \\
5 & VI & 2 & Kufri Badshah, Kufri Puskar \\
6 & VII & 2 & $91-P-27$, Kufri Arun \\
7 & VIII & 2 & Kufri Chipsona-2, B-420(2) \\
8 & IX & 1 & J/93-3128 \\
9 & X & 1 & JX/576 \\
10 & & &
\end{tabular}

Table 4: Average intra and intra cluster $D^{2}$ values (in first row) and distance $\left(\sqrt{ } D^{2}\right)$ (in second of each cluster row) among thirty five genotypes of potato for growth characters.

\begin{tabular}{|c|c|c|c|c|c|c|c|c|c|}
\hline Cluster & I & II & III & IV & $\mathbf{V}$ & VI & VII & VIII & IX \\
\hline \multirow[b]{2}{*}{ I } & 94.68 & 119.48 & 178.45 & 123.77 & 150.03 & 130.17 & 262.35 & 253.68 & 290.37 \\
\hline & 9.73 & 10.93 & 13.35 & 11.12 & 12.24 & 11.40 & 16.19 & 15.92 & 17.04 \\
\hline \multirow[t]{2}{*}{ II } & & 0.00 & 212.13 & 31.33 & 134.31 & 211.78 & 304.43 & 281.62 & 166.83 \\
\hline & & & 14.56 & 5.59 & 11.58 & 14.55 & 17.44 & 16.78 & 12.91 \\
\hline \multirow{2}{*}{ III } & & & 90.28 & 179.87 & 309.70 & 184.11 & 258.86 & 265.62 & 408.03 \\
\hline & & & 9.50 & 13.41 & 17.59 & 13.56 & 16.08 & 16.29 & 20.19 \\
\hline \multirow{2}{*}{ IV } & & & & 0.00 & 145.69 & 227.65 & 305.68 & 169.65 & 204.65 \\
\hline & & & & & 12.07 & 15.08 & 17.48 & 13.02 & 14.30 \\
\hline \multirow[b]{2}{*}{ V } & & & & & 131.72 & 238.76 & 478.65 & 361.53 & 398.87 \\
\hline & & & & & 11.47 & 15.45 & 21.87 & 19.01 & 19.97 \\
\hline \multirow{2}{*}{ VI } & & & & & & 0.00 & 160.48 & 405.74 & 383.06 \\
\hline & & & & & & & 12.66 & 20.14 & 19.57 \\
\hline \multirow{2}{*}{ VII } & & & & & & & 74.55 & 373.21 & 271.57 \\
\hline & & & & & & & 8.63 & 19.31 & 16.47 \\
\hline \multirow{2}{*}{ VIII } & & & & & & & & 0.00 & 260.54 \\
\hline & & & & & & & & & 16.14 \\
\hline \multirow{2}{*}{ IX } & & & & & & & & & 0.00 \\
\hline & & & & & & & & & 0.00 \\
\hline
\end{tabular}

Table 5. Average intra and inter cluster $D^{2}$ values (in first row) and distance $\left(\sqrt{ } D^{2}\right)$ (in second of each cluster row) among thirty five genotypes of potato for quality characters.

\begin{tabular}{|c|c|c|c|c|c|c|c|c|c|c|}
\hline Cluster & I & II & III & IV & $\mathbf{V}$ & VI & VII & VIII & IX & $\mathbf{X}$ \\
\hline \multirow{2}{*}{ I } & 2.83 & 5.06 & 6.94 & 7.40 & 8.41 & 8.98 & 6.72 & 14.09 & 12.59 & 8.57 \\
\hline & 1.68 & 2.24 & 2.63 & 2.72 & 2.90 & 2.99 & 2.59 & 3.75 & 3.54 & 2.92 \\
\hline \multirow{2}{*}{ II } & & 3.16 & 5.87 & 8.25 & 14.13 & 9.11 & 11.22 & 18.75 & 12.20 & 13.71 \\
\hline & & 1.77 & 2.42 & 2.87 & 3.75 & 3.01 & 3.34 & 4.33 & 3.49 & 3.70 \\
\hline \multirow{2}{*}{ III } & & & 2.97 & 9.92 & 9.50 & 6.30 & 13.30 & 19.21 & 11.03 & 10.77 \\
\hline & & & 1.72 & 3.14 & 3.08 & 2.50 & 3.64 & 4.38 & 3.32 & 3.28 \\
\hline \multirow{2}{*}{ IV } & & & & 3.05 & 6.96 & 7.89 & 14.02 & 15.55 & 14.40 & 12.94 \\
\hline & & & & 1.74 & 2.63 & 2.80 & 3.74 & 3.94 & 3.79 & 3.59 \\
\hline \multirow{2}{*}{ V } & & & & & 1.85 & 7.03 & 12.12 & 21.61 & 13.42 & 6.57 \\
\hline & & & & & 1.36 & 2.65 & 3.48 & 4.64 & 3.66 & 2.56 \\
\hline \multirow{2}{*}{ VI } & & & & & & 4.60 & 10.16 & 22.79 & 5.05 & 16.45 \\
\hline & & & & & & 2.14 & 3.18 & 4.77 & 2.24 & 4.05 \\
\hline \multirow{2}{*}{ VII } & & & & & & & 8.16 & 18.96 & 9.91 & 17.66 \\
\hline & & & & & & & 2.85 & 4.35 & 3.14 & 4.20 \\
\hline \multirow{2}{*}{ VIII } & & & & & & & & 9.89 & 18.53 & 26.75 \\
\hline & & & & & & & & 3.14 & 4.30 & 5.17 \\
\hline \multirow[b]{2}{*}{ IX } & & & & & & & & & 0.00 & 29.97 \\
\hline & & & & & & & & & & 5.47 \\
\hline \multirow{2}{*}{$\mathbf{X}$} & & & & & & & & & & 0.00 \\
\hline & & & & & & & & & & 0.00 \\
\hline
\end{tabular}


Sanjay Datta et al. / J. Appl. \& Nat. Sci. 7 (1) : 235 - 241 (2015)

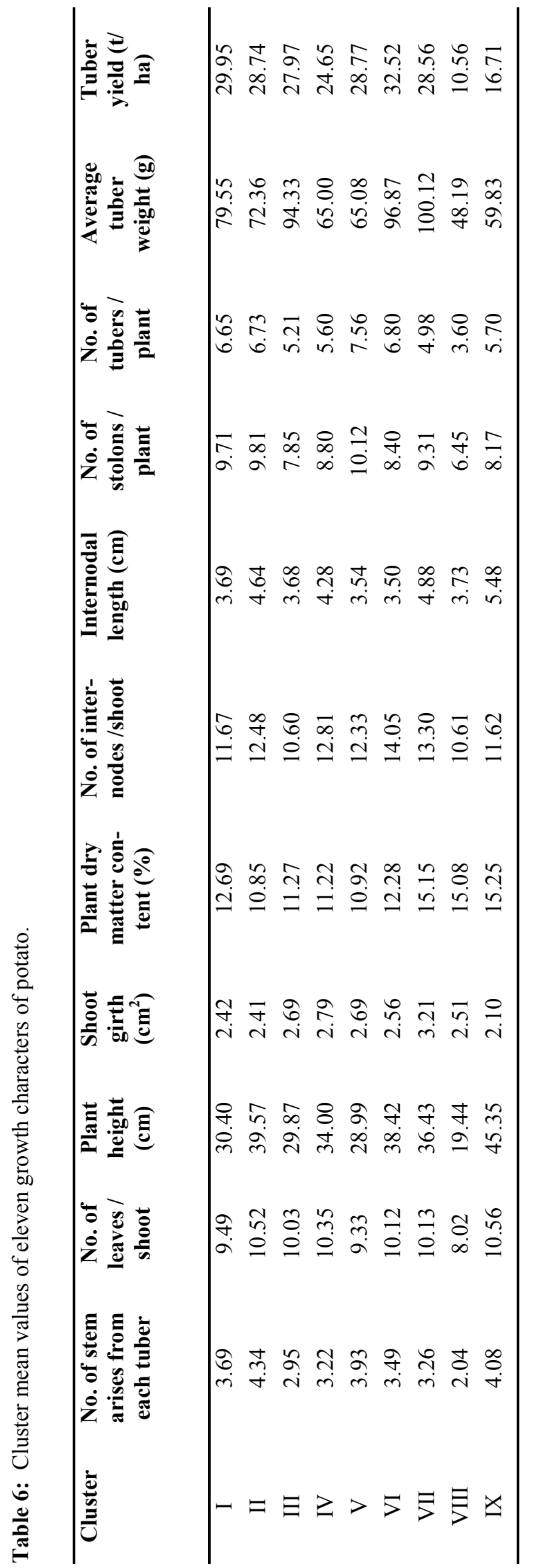

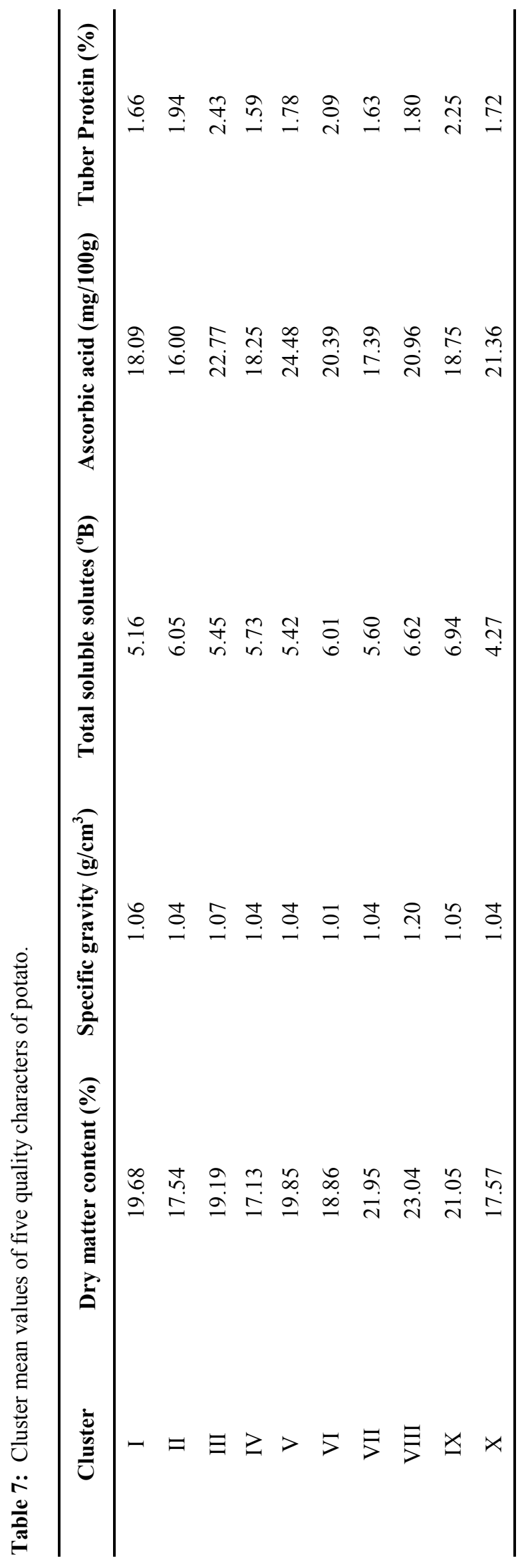


Table 8: Contribution of growth characters to create diversity in potato genotype.

\begin{tabular}{clc}
\hline S. N. & Characters & Contribution (\%) \\
\hline 1. & Number of stem arises from each tuber & 0.17 \\
2. & Number of leaves per shoot & 0.00 \\
3. & Plant height $(\mathrm{cm})$ at 40 days after planting & 0.50 \\
4. & Shoot girth $\left(\mathrm{cm}^{2}\right)$ & 0.17 \\
5. & Plant dry matter content $(\%)$ & 13.61 \\
6. & Number of internodes per shoot & 9.24 \\
7. & Internodal length $(\mathrm{cm})$ & 14.45 \\
8. & Number of stolons per plant & 1.01 \\
9. & Number of tubers per plant & 27.56 \\
10. & Average tuber weight (g) & 31.76 \\
11. & Tuber yield (t/ha) & 1.51 \\
\hline
\end{tabular}

Table 9: Contribution of quality characters to create diversity in potato genotype.

\begin{tabular}{clc}
\hline S. N. & Characters & Contribution (\%) \\
\hline 1. & Tuber dry matter content $(\%)$ & 18.99 \\
2. & Specific gravity $\left(\mathrm{g} / \mathrm{cm}^{3}\right)$ & 15.46 \\
3. & Total soluble solutes $\left({ }^{\circ} \mathrm{B}\right)$ & 20.00 \\
4. & Ascorbic acid $(\mathrm{mg} / 100 \mathrm{~g})$ & 24.70 \\
5. & Tuber Protein $(\%)$ & 20.84 \\
\hline
\end{tabular}

homogenous nature between and within groups, respectively (Mandal, 2003). Study of clustering pattern indicated that genotypes related by pedigree fell in either same cluster or in cluster with low inter cluster distances. High inter-cluster distances were the main cause of heterogeneity in composition of clusters.

Cluster mean for characters: A perusal of these cluster means for different characters indicated considerable difference between the clusters for all the characters (Tables 6 and 7). For quality characters highest mean values recorded for tuber dry matter content (23.04\%) and specific gravity (1.20) in cluster- VIII. Maximum cluster mean value for protein found in cluster- III $(2.43 \%)$ and for ascorbic acid it was cluster V (22.77 $\mathrm{mg} / 100 \mathrm{~g}$ of tuber) but cluster- IX shows highest mean values for total soluble solid content of tuber (6.94\%). For growth characters, cluster-II had the highest cluster mean values for number of stem arises from each tuber (4.34) but cluster - IX had maximum value for number of leaves per shoot $(10.56)$, plant height $(45.35 \mathrm{~cm})$ at 40 days after planting, plant dry matter content $(15.25 \%)$ and internodal length $(5.48 \mathrm{~cm})$. Pandey and Gupta (1995) also observed comparatively higher cluster mean values under various clusters for characters like dry weight, protein content, TSS, internodal length while working with 16 varieties of potatoes. So, it may be seen here that the findings of the present investigation have corroborated well the results of the research work of Pandey and Gupta (1995).

Contribution of different characters towards divergence : The per cent contribution for growth characters towards genetic divergence ranged from $0.00 \%$ to $31.76 \%$ (Table 8 ) and for quality characters $15.46 \%$ to $24.70 \%$ (Table 9). Average tuber weight contributed maximum $(31.76 \%)$, followed by number of tuber per plant $(27.56 \%)$, internodal length $(14.45 \%)$ and plant dry matter content $(13.61 \%)$ for growth characters. For quality characters, ascorbic acid content (24.70\%), protein content of tuber $(20.84 \%)$ and TSS of tuber $(20.00 \%)$ contributed effectively towards genetic divergence. The greater diversity in the present materials was due to these four yield attributing characters and three quality characters, which will offer a good scope for improvement of yield as well as quality through rational selection of parents genotypes for potato breeding.

\section{Conclusion}

Study of clustering pattern keeping in view the pedigree of genotypes indicated that genotypes related by pedigree fell in either same cluster or in cluster with low inter cluster distances. Kufri Jawahar and MS/92-1090 had one parent Kufri Jyoti to be common and were distributed in cluster-IV and cluster-III. Twelve Indian released varieties (viz., Kufri Badshsh, Kufri Anand, Kufri Ashoka, Kufri Bahar, Kufri Puskar, Kufri Chipsona-2, Kufri Jawahar, Kufri Jyoti, Kufri Pukhraj and Kufri Sutlej, Kufri Lalima and Kufri Arun) were distributed in different clusters indicating considerable genetic diversity in material. The findings indicated that use of parents selected from the same cross or from a cross involving a common parent should be avoided in hybridization. High inter-cluster distances were the main cause of heterogeneity in composition of clusters. The highest genetic distance for quality was observed between cluster-IX (J/93-3128) and cluster-X (JX/576) and for growth characters it was found between cluster $-\mathrm{V}$ and VII. Average tuber weight, number of tuber/ plant, internodal length and plant dry matter content 
for yield attributing characters and ascorbic acid content, protein content and TSS of tuber for quality characters, showed maximum contribution towards total divergence among the genotypes. So, these traits will offer a good scope for improvement of yield as well as quality through rational selection of parents genotypes for future potato breeding involving the germplasm investigated in the present research work. The results broadly showed there was no parallelism between geographical and genetic divergence.

\section{REFERENCES}

Barone, A., Nunziata, A., Ruggieri, V., Greco, N. and Frusciante, L. (2010). Genetic Diversity within Wild Potato Species (Solanum spp.) Revealed by AFLP and SCAR Markers. American Journal of Plant Science, 1: 95-103.

Esfahani, S.T., Shiran, B. and Balali, G. (2009). AFLP markers for the assessment of genetic diversity in European and North American potato varieties cultivated in Iran. Crop Breeding and Applied Biotechnology, 9: 75-86.
Mahalanobis, P.C. (1936). Studies on generalized distance in statistics. Proc. Nat. Inst. Sci., 12: 49-55.

Mandal, M.A.A. (2003). Improvement of potato (Solanum tuberosum L.) through hybridization and in-vitro culture technique. Ph. D. Thesis, Rajsahi University, Rajasahi, Bangladesh.

Pandey, M.C. and Gupta, P.K. (1995). Genetic divergence in some Indian and exotic varieties and advanced potato hybrids. Journal of Indian Potato Association, 23: 318-328.

Panse, V.G. and Sukhatme, P.V. (1989). Statistical Methods for Agricultural Workesr, ICAR, New Delhi.

Rao, C.R. (1952). Advanced statistical methods in biometrical research. John Wiley and Sons, New York pp. 390.

Regassa, D. and Basavaraja, N. (2007). Genetic divergence in cultivated potato germplasm. Potato Journal, 34: 57-58.

Razvy, M.A., Haydar, A., Ahmed, M.B., Hannan, M.M., Mandal, M.A., Salahin, M., Karim, R. and Hossain, M. (2007). Analysis of Genetic Diversity in Some Potato Varieties Grown in Bangladesh. Middle-East Journal of Scientific Research, 2 (3-4): 143-145.

Swaminathan, M.S. (1999). Potato for global food security. In: Potato: Global research and development, Vol. 1(S. M. Paul Khurana, G.S. Shekhawat, B.P. Singh, and S.K. Pandey, Eds.), Indian Potato Association, Shimla. pp 8-12. 